\title{
Bermuda Grass Pollen IgE Measurement
}

National Cancer Institute

\section{Source}

National Cancer Institute. Bermuda Grass Pollen IgE Measurement. NCI Thesaurus.

Code C130068.

A measurement of the Bermuda grass (Cynodon dactylon) pollen IgE in a biological specimen. 